\title{
Exploring Teachers' Motivation for Teaching and Professional Development in Ethiopia: Voices from the Field
}

\author{
Fekede Tuli Gemeda (Corresponding author) \\ Departement of Teacher Education, Ambo University \\ P.O.Box 15, Ambo, Ethiopia \\ Tel: 251-911-347-772 E-mail: fekede2010@gmail.com
}

\author{
Päivi Tynjälä (Professor) \\ Finnish Institute for Educational Research, University of Jyväskylä \\ P.O. Box 35, FI-40014, University of Jyväskylä, Finland \\ Tel: 358-50-400-9464 E-mail: paivi.tynjala@jyu.fi
}

Received: April 17, 2015 Accepted: May 5, 2015 Published: May 5, 2015

doi:10.5296/jse.v5i2.7459 URL: http://dx.doi.org/10.5296/jse.v5i2.7459

\begin{abstract}
Teachers' work, learning, and professional development are central to any effort aiming at improving schools. Consequently, teachers must consider themselves as a lifelong learner, engage in continuous professional learning and apply that learning to improve student learning and achievement. This article explores teachers' motivation for teaching and professional development in secondary schools in Ethiopia. Data were collected via interviews and focus group discussions from 32 teachers. The analysis of the collected information revealed low salary and the absence of link between performance and reward as major motivational challenges for teachers. The identified motivational challenges were explained from the viewpoint of different motivational theories.
\end{abstract}

Keywords: Professional development, Motivational theories, Teachers, Ethiopia, Salary 


\section{Introduction}

Teachers play a vital role in ensuring high quality of education for all. Numerous research studies have indicated that the quality of an educational system cannot outperform the quality of its teachers (Harris \& Jones, 2010). In order to remain competitive and productive in today's knowledge based world, as Majerič, Leskošek \& Erpič (2011) put it, teachers are constantly required to train and update their knowledge. At the same time, it is argued that preservice teacher education cannot fully equip teachers with the knowledge and skills necessary for a lifetime (Heikkinen, Jokinen, \& Tynjälä, 2008, 2012). To keep pace with a fast changing world, learning can't stop at graduation; rather the rest of teachers' life should be a continuous effort to learn and develop. The ultimate goal of teachers' professional development is to improve student achievement and learning (Guskey, 2000; Darling-Hammond et al, 2009). This is based on the assumption that professional development capacitates teachers by enhancing their knowledge and skills, and enhanced knowledge and skills will lead to improvement in classroom practice, and improved classroom practice in turn will improve student achievement and learning. This process of updating teachers' knowledge and skills depend on various factors such as availability of effective professional development programs, teacher's readiness and willingness to learn and unlearn, teachers' commitment to apply the knowledge and skills gained, teachers' job satisfaction and motivation, to mention a few.

The present study examines the motivation of teachers for teaching and participation in professional development opportunities in Ethiopian secondary schools. Motivations of teachers play a vital role in teaching learning process. According to Ololube (2005), job satisfaction and motivation are not only crucial to the long-term growth of any educational system but also very essential in the lives of teachers as they form the fundamental reason for working. Bennell and Akyeampong (2007) state that achieving better learning outcomes for learners in developing countries depend fundamentally on improvements in teaching. Thus, ways to increase teacher motivation and capabilities can be assumed to be central to any systematic attempt to improve learning outcomes. Likewise, Chireshe and Shumba (2011) state that a motivated teacher leads to motivated students and good performance. Conversely, teachers who are not motivated to teach or are not satisfied with their career can impact negatively on student learning and the schools (Mendel, 1980). Arguably, teachers' satisfaction profoundly influences teachers' job performance, which in turn influences student learning.

Zhilla (2013) succinctly put that employees' motivation can only be attained by realizing that their individual needs or goals are aligned with organizational goals or achievement. Adding to this, Zhilla remarked that organizations need to extract various internal and external motivators for its workers so that they can increase their motivation in order to get long run success. Otherwise, as Rasheed, Aslam and Sarwar (2010) state, efficiency suffers with demotivated personnel. The same authors explained that the courage and dedication for high performance work can only be achieved if teachers would be willing to give their best. Recent work on teacher motivation also provides evidence for links between teachers' moti- 
vation and their engagement, commitment and persistence in teaching and their inclination to become involved in professional development (Karabenick\& Conley, 2011).

Various factors motivate people differently depending upon the nature of an organization and other factors. For example Rasheed, Aslam and Sarwar (2010) in their study conducted in higher education context reveal that compensation is a strong factor that motivates teachers. When pay is perceived as equitable, is commensurate with job demands, individual skill level, and community pay standards, satisfaction is likely to be the result (Zhilla, 2013). In the same vein, Bennell (2004) remarked that pecuniary motives are likely to be dominant among teachers in low income countries where pay and other material benefits are often too low for individual and household survival needs to be met.

However, Barmby (2006) points out that teacher motivation is influenced less by externally initiated factors such as salary. Fuhrmann (2006) states that money is influential factor at every stage but at the same time it is not necessary that money alone can increase motivation of every worker and that there are intangibles (for instance empowerment, recognition and feedback) that are primary motivators for the workers inspiration to perform effectively.

In their study, Mulkeen et al. (2007) report that in Ghana, Guinea, Madagascar, Tanzania and Uganda there are a variety of unattractive conditions of service for teachers that make teaching as a profession to be less attractive to school leavers. These unattractive conditions include perceived low salary, unattractive work locations, unprofessional treatment of teachers, arbitrary teacher deployment systems, lack of professional development opportunities and insufficient supportive supervision. In their study that examines 30 different countries with regard to teacher salary and national achievement, Akiba et al. (2011) revealed that low teacher salary often leads to teacher dissatisfaction and higher attrition rates.

It is indisputable that lack of well-qualified, satisfied and motivated teachers contributes to having dysfunctional education, an education that cannot produce an inquiry, creative and problem-solving mind, an education that cannot equip learners with the required tools to confront the challenges of the present and future. Therefore, government, school leaders and administrators should identify and analyze factors that affect teachers' motivation and understand and address them. It can be assumed that when teachers' needs are met, they will be motivated to be effective in their performance thereby achieving organizational goals. In this regard, Klang (2006) argues, “If you don't feel well, you don't work well; if you don't work well, your full potential is never realized." Thus, teacher motivation is an important factor in the realization of the school's core mission.

There are several theories put forward to explain why people are motivated or not, why employees behave in a particular way and what determines their actions. This study is rooted in Maslow's Hierarchy of needs, Herzberg two-factor theory, Expectancy Theory and Equity Theory to explain how need satisfaction motivates teachers. In the light of these theories the study examines teachers', perceptions of their motivation for teaching and professional development in Ethiopian school system. 


\section{Theoretical Framework}

\subsection{Maslow’s Hierarchy of Needs}

Maslow (1954) stated that a person has five fundamental needs: physiological, security, social, esteem, and self-actualization. The physiological needs include pay, food, shelter and clothing, good and comfortable work conditions etc, whereas the security needs include, for example, the need for safety, fair treatment, protection against threats, and job security. Social needs contain needs such as being loved, accepted, part of a group etc, and esteem needs include the need for recognition, respect, achievement, autonomy, and independence, for example. Finally, self-actualization needs, which are the highest in the level of Maslow's need theory, pertain to realizing one's full potential or self-development. According to Maslow, people arrange their needs in order of importance. Once individuals have satisfied one need in the hierarchy, it ceases to motivate their behavior, and they are motivated by the need at the next level up the hierarchy. Thus, we are not driven by all the needs at the same time and only one need will dominate our personality. Which one it will be depends on which of the others have been satisfied. For example, hungry people feel no urge to satisfy the higher need for esteem. They are preoccupied with satisfying the physiological need for food, not with obtaining approval and esteem from other people. It is only when people have adequate food and shelter and when the rest of the lower needs are satisfied that they are motivated by needs that rank higher in the hierarchy (Maslow, 1954; Schultz \& Schultz, 2009). Maslow's work on motivation has received wide recognition in terms of its intuitive logic and ease of understanding. However, the theory receives criticism centered on his research methods and lack of experimentally generated supporting data (Schultz \& Schultz, 2009).

\subsection{Herzberg's motivation-hygiene theory}

According to Herzberg's motivation-hygiene theory, factors that make employees feel good about their work are different from factors that make them feel bad about their work. Thus, the theory considers job satisfaction and dissatisfaction as independent phenomena. In Herzberg's theory, factors related to job satisfaction are divided into two categories. First, there are hygiene factors which include: company policy and administration, technical supervision, salary, work environment and interpersonal relationships. According to Herzberg, inadequacies in these factors will lead to job dissatisfaction but, when adequate, they do not necessarily lead to job satisfaction but only prevent job dissatisfaction. Second, there are motivating factors, which consist of achievement, recognition, responsibility, advancement and the intrinsic interest in the work itself. The presence of motivating factors in the work situation leads to satisfaction but does not prevent job dissatisfaction. The weakness of Herzberg theory is that it over-generalizes his hypothesis about motivation and hygiene factors by claiming that they operate in the same way for everyone. Yet, in spite of such criticisms, the two-factor theory may help education managers focus on job content and on enriching the workplace environment. Moreover, the notion of improving satisfiers and reducing or removing dissatisfiers can help education managers see that the existence of 
dissatisfiers does not mean an end to motivation in itself, given that there are motivating factor as well (Al-Habsi, 2009).

\subsection{Expectancy theory}

Expectancy Theory of motivation is grounded on the works of several theorists, among them Vroom, Peak, and Porter and Lawler (Estes \&Polnick, 2012). As they describe, the basic tenet of expectancy theory is that people are influenced by the expected results of their actions. When deciding amongst behavioral options, individuals select the most motivating option which is seen as a function of three perceptions: expectancy (the belief that effort will lead to the desired performance), instrumentality (the belief that if one meets performance expectations, one will receive a greater reward) and valence (the value one personally places on the rewards). Hence, expectance theory can be summarized as

\section{Motivation Forces $=$ Expectancy $\mathrm{x}$ Instrumentality $\mathrm{x}$ Valence}

According to this theory, if an individual believes that a high level of performance is instrumental for the attainment of other outcomes (such as a pay increase), and/or if he believes that a high performance level will be instrumental for avoiding other outcomes (such as being fired), then that individual will place a high valence upon performing well. Applied to the field of teaching, if teachers work hard, achieve high performance and are rewarded, their level of motivation will be determined by the degree of valence i.e. whether the reward is highly valued by them or not. If hard work and high performance are not appropriately rewarded, staff morale may decline, as high performance will not be perceived as being instrumental in bringing valued rewards (Al-Habsi, 2009; Estes \& Polnick, 2012). However, according to Baron et al. (2002) the expectancy theory does not adequately consider people's cognitive limitations and they do not believe that people are as rational and calculating in their decision-making as suggested by the expectancy theory.

\subsection{Equity Theory}

Stacy Adams (Adam, 1965, Fiore, 2009) developed detailed equity theory of motivation. It explains how people strive for fairness and justice in social exchanges or give and take relationships (Geren, 2011). The major components of exchange relationships in this theory are inputs (e.g. effort, experience, education, and competence, etc.) and outcomes (e.g. salary levels, increases, recognition, etc.). Equity theory focuses on people's feelings of how fairly they have been treated in comparison with the treatment received by others. According to Ramlall (2004) Equity theory recognizes that individuals are concerned not only with the absolute amount of rewards they receive for their efforts, but also with the relationship of this amount to what others receive. Inequity is said to exist when the ratio of an individual's outcomes to inputs departs to a significant degree from the ratio perceived for the reference source. Thus, people may feel that they are under rewarded in terms of what they put into a job in comparison with what other workers are getting for their contributions. This might happen when people consider themselves much hard workers than other employees, but are paid the same as everyone else. Perception of inequity in the workplace will lead to a variety of options for the employees. These options include changing the input they are required to 
make (e.g. time, effort, hard work, commitment, etc.) or outcomes (benefits such as salary, recognition, job-security, etc.) or the basis of comparison (e.g. grade responsibility, position, etc.) or withdrawing from the situation entirely, quitting the job as a way of restoring balance between perceived inputs and outcomes (Evans, 2001; Ramlall, 2004; Miner, 2005; Al-Habsi, 2009; Geren, 2011). Equity theory offers a useful approach to understanding a variety of social relationships and interpersonal interactions in organizations. However, it is also subjected to some criticism for being fails to capture the complexity of the real world, and that it ignores the impact of different cultural contexts on people's perceptions of inequity (Yung-Hsiang, 2000).

In summary, motivational theories provide several approaches to understand job satisfaction and job related motivation. In the present study we applied the four aforementioned theories for exploring teachers motivation to professional development in Ethiopia. Education is a dynamic field that continuously changes and expands. As a result, teachers must consider themselves as a lifelong learner and engage themselves in the continuing learning process, where they can develop the skills and knowledge essential to meet an ever-evolving and increasingly complex world. Professional development is very important to keep teachers abreast of the current education change and demand. To this end, teachers need to be motivated, satisfied, encouraged and supported to learn and apply the new knowledge and skills acquired from professional development activities. Hence, educational administrators, professional developers and policy makers need understanding about factors that affect teachers' motivation and influence the realization of the change that we are looking for.

\section{Purpose of the Study}

The purpose of this study was to explore teachers' motivation for teaching and professional development in secondary schools in Ethiopia from participants' perspectives with the following guiding research questions:

1) What are the most important factors influencing teachers' motivation for teaching and professional development?

2) How teachers' motivation can be explained in light of the motivational theories?

\section{Methodology}

This study is a part of larger study about professional development of teachers in Ethiopia. The study relies on qualitative research methodology. Data were collected via focus group discussions and semi-structured interviews from 32 teachers working in different secondary schools. The selection of participants was purposive and involved teachers with different work experience. The interviews lasted 45- 90 minutes and the focus group discussions lasted $60-120$ minutes.

The collected data at each school site were recorded and transcribed to create a text reflecting a discourse around teacher professional development. The transcripts were coded and categorized by looking for conceptual patterns. By reading the categorized constructed 
meaning of the respondents within the context of the research, we identified participants' experience of their motivation for teaching and professional development.

\section{Results}

Our analysis showed that the two most important factor influencing teachers' motivation for teaching and professional development in the Ethiopian secondary school contexts were the salary and the missing link between performance and reward. In the following, we describe in detail how the teachers dealt with these themes. We also interpret the teachers' accounts in the light of the four motivational theories described earlier.

\subsection{Salary}

The data obtained from the participants during focus group discussions and interviews indicated that the salary of teachers was considered as a key issue in teachers' motivation and development. The participants explained that teachers are underpaid. They further explained that low pay for teachers has a devastating effect on the whole process of education by demoralizing teachers, devaluing their work and loosing teachers to better paying professions. The following excerpt was taken from the focus group discussion as illustrative of this:

... the teaching profession is the least paid and most disrespected profession in the country. The major reason for this is that the low salary of teachers. When we compare the salary and other benefits teachers gain with other professionals, it is disappointing. We have developed strong hatred toward the profession. These days the teaching profession is considered as abridge occupation. Nobody wants to stay in the teaching profession unless she or he fails to find another job. That means we are coming to school to meet attendance demand. Our motivation to teach is dead. Our commitment to effect any change has been lowered. We lost our passion for the profession. All those things affect our effort to develop ourselves and perform the teaching profession effectively... The teaching profession is not only losing well experienced teachers to other professions but also failed to attract brightest candidates to the profession...

The quotation above suggested that the respondents unanimously felt discomfort and not pleased with the salary paid for the teachers. They explained that low salary of teachers change the attitude of teachers toward the teaching profession and made to lose interest. They further explained that this low salary caused basic needs to be unmet for teachers, declining prestige and hatred for the teaching profession. Schaffer (cited in Abdel Fattah, 2010)argued that individuals use monetary rewards and salaries not only to satisfy their physical needs such as food, shelter, and clothing but also their psychological needs as a symbol of achievement and recognition. If the salary earned by teachers' does not materializes in this way the fulfillment of basic needs, described by Maslow, wouldn't be met.Only when these basic needs have been met is it possible for higher-order needs, which are the basis of true job satisfaction, to be realized (Bennell, 2004). For Herzberg et al. (1959), salary is a hygiene factor that leads to dissatisfaction when not experienced as adequate. Research by McShane and Glinow (2003) shows that people who are dissatisfied with their jobs often quit and pursue other careers, thereby increasing turnover. Equity theory also suggests that the amount 
of financial compensation that an individual receives should be perceived as equitable to satisfy and motivate workers (Zhilla, 2013).

\subsubsection{Basic needs remain unmet}

As described earlier, teachers participated in the study unanimously stated that the salary for teachers is little and inadequate to cover their basic needs (foods, cloth and shelter). They also felt that the situation demoralizes the teaching force and affect teachers professional commitment. Here is an example of excerpt taken from the data:

.... the government pays us the lowest salary, which can hardly cope up with the current expense of life. Moreover, there is no change in our salary despite the fact that the inflation rate is very high. For a long time since our primary concern has become the issue of basic needs. If the money you earned from your profession does not meet your basic needs, what is the meaning of staying in that profession? For a hungry teacher, the primary concern is addressing the basic needs, looking to fulfill the needs for food and accommodation. Our concern to address our basic needs surpass our concern to help students learn. Therefore, our attention is not on improving our knowledge and skills to help our students learn rather looking on ways by which we can find a better job outside the teaching profession...

In the data, there appeared several teachers' observations that low salary coupled with high inflation rate makes the living cost unbearable for teachers. Owing to this, the quest for basic needs was described as dominating their activities. Student learning, which is the fundamental purpose of school becomes secondary issue. The situations, as the teachers explained, affect their motivation to perform teaching responsibility effectively and forced them to look for other payable job. Participants experience corroborated what Maslow (1954) states as physiological needs are the human instinct to survive, and remarked that they are the needs that human being will seek for and satisfy before the other needs in the growth needs will emerge. For instance, hungry teacher will not pay attention on the learning of his/her students, rather will be preoccupied with the need for food. Based on the application of this theory to organizational settings, it can be argued that people who do not meet their needs at work will not function efficiently.

\subsubsection{Declining prestige}

The teachers participated in the study deduced that the low income level of teachers has led the profession to lose the respect it deserves. Here is an example of a substantive explanation by an informant regarding the issue at hand:

...becoming a teacher is an economic suicide. We have been trying our best expecting that the situation might change one day. However, the situation is getting worse and worse. Now we lost hope about everything. Our attachment to the teaching profession is eroded. Being a teacher is a punishment and a sign of poorness. Since our today's society values people entirely with their income status, teachers lost the respect they deserve. Because of this, teaching has nowadays become the most disrespected profession in the country. As a solution what everyone think is leaving the profession. That is why a lot of teachers are attending 
another degree program on partime base outside the teaching profession instead of developing and growing within the teaching profession....

In the above description, the participant emphasizes that in addition to making the basic needs out of reach, the low salary of teachers contributes for the loss of respect for the teachers and teaching profession. According to the respondents, these conditions enforce them to develop hatred toward their profession and lead them to attend other program with the intention to earn other degree and leave the profession. As we observe in participants description, the respondents believe that their profession is not offering them reasonable pay that bears the current living cost, which in turn compromises teaching and professional development activities. Moreover, the fall of teachers pay below the minimum wage has a damaging effect on the social status or image of teachers.

In our data the teachers also complained that they are paid less in comparison with other civil servants, which is a double demotivating factor for them. The participants also described that poor working conditions and workload frustrated them and were a disincentive to be committed to their profession and aspire to grow with in the teaching profession. Here is an example of excerpt taken during one of such interview:

...if I will be given a new opportunity to select a profession I would not consider and choose teaching as my profession. The reason is that teaching is the least paid and most disrespected profession. The economic return from the profession is very low and don't address your basic needs, let alone other concerns. Now being a teacher at schools is considered as a doorway to financial insecurity and sign of poorness. When we compare our pay with the other civil servants with the same qualification and years of experience, they are earning better and reasonable salary. Therefore, we consider joining teaching profession as a punishment, which is disgraceful. Our commitment to the profession and educating the children is shifted to dealing with ways of addressing our pressing basic needs. Moreover, inexperienced and relatively unqualified individuals, who lack adequate profile for the leadership position, lead the profession. The working conditions are neither conducive. We are bombarded by multiple tasks, both administrative and instructional. All these issues affect our morale and motivation to stay in the profession. You cannot think to develop yourself in a profession that you are not interested to stay in...

...the situation of teachers and teaching profession is getting worse and worse. Teachers are demoralized because of low salary, lack of incentives, poor working conditions, ineffective leadership. This condition threatens the profession as it drive away passionate and dedicated individuals out of the profession...

As the examples above show the participantsfelt that the teaching profession is not enjoying the privileges that other civil servants are enjoying. In teachers' interpretation unfair treatment of teachers and teaching profession convey a message that teaching is less important than the other professions. This situation undermines their social status and enforces them to leave the profession to other well-paying jobs. 
According to Equity theory, people are motivated if they experience equity/fairness at work. Baron et al. (2002) assert that people make judgments or comparisons between their own inputs at work (e.g. their qualifications, experience and effort) and the outcomes they receive (such as pay and fringe benefits, status and working conditions). Participants' experience revealed that salary and other benefit for teachers are low compared to employees who work in other government departments, and this situation impacts negatively on their levels of motivation and job satisfaction. In the context of this study, the theory states that teachers compare themselves to others with regard to outcomes and inputs at work, and discrepancies in ratios can motivate them to take action. The choice of action may include changing the level of commitment to the organization, changing the rewards from work, or even quitting (Spector, 2008).

\subsection{Missing link of performance-reward}

Another issue related to teacher motivation in our data is the absence of link between performance / effort and reward. The participants explained that there is no connection between effort and achievement in the work. The participants felt that if someone is actively engaged in professional development and improves his/her knowledge and skills which in turn improves students' learning and achievement, there should be some kind of reward for this effort. According to the teachers, the existing system does not make any difference between teachers based on their performance, which the participants claim unfair and discourage their effort to participate in professional development. The following examples of excerpts taken during focus group discussion and interview illustrate this view;

...there is no any difference between those who are working hard and who are not.This affects the motivation and enthusiasm of teachers' who relatively perform better. The existing system does not encourage hardworking. As to me, those who are working hard should be recognized and rewarded in a transparent way. What we are currently observing in our school is obnoxious. For instance, if we look at the way teachers are assigned in a leadership position or the way teachers are selected for further training it is disgraceful. It lacks transparency and scientific base. The only thing we are sure about the practice is that the procedures are not in favor of hardworking. If you want to know this just compare the profile, experience and performance of those teachers....

...the issues of teacher development is entangled with entrenched problems. The environment does not encourage teachers' engagement in professional development. There is no any recognition or reward for those teachers who actively engage in professional development. This practice not only kills the motivation to participate but also convey a message that professional development is not important. If the participation does not make any different between those who participated and those who are not, what the need of wasting your time...

Participants' descriptions affirm what Wright (1985) state as satisfaction of teachers is closely related to recognition. He further explains that teachers get motivation from the recognition of their achievements and accomplishments by their head, when they get appreciated for their valuable contribution or receive constructive feedback in order to correct 
their flaws. Conversely, our data show that teachers felt that they are not recognized and rewarded for the contribution they make for the success of the teaching learning process.

Expectancy theory of motivation (Porter \& Lawler, 1968) postulated that rewards would lead to satisfaction if the reward was viewed as leading to a desired outcome. Based on expectancy theory an individual can only be successful if he/she believes that he/she can be successful in the task, sees the connection between the success and the activity, and values the results of the success (Huitt, 2001). Likewise, Kroth (2007) described that if an employee believes that good work will result in a successful project, but that the probability of being rewarded for success is zero, the employee will not be motivated. In opposition to what the participants experienced, Vroom and Deci (1992) stated that in equity theory people will be most satisfied and work most effectively when they believe that their rewards or outcomes are in balance with their inputs. In equity theory, it is noted that people must be rewarded equitably; those who are over-rewarded or under-rewarded can become uncomfortable. Herzberg's two-factor motivational theory explained opportunity for recognition, achievement, and personal growth as motivational factors that drive individuals to attain personal and organizational goals. Conversely, the absence of these will lead to demotivation as it is also stated by the participants.

\subsection{Unattractive profession}

Ideas we have assembled from discussions with our informants signify that the low pay for teachers and the declining of teachers' prestige contributed for unattractiveness of the teaching profession. The respondents explained that the conditions wreaked havoc on the education system in general and teaching profession in particular. According to them, the teaching profession is the least preferred profession in the country. The teachers state that the teaching profession is not only suffering from failure to attract better candidates to the teaching profession but it is also unable to retain the skilled and knowledgeable teachers in the profession. The following excerpt by the focus group discussion participants is affirmative of this view:

...I lost hope about the teaching profession. Our daily discussion is largely surface around salary, inflation etc instead of teaching learning process. This is the reality. The issue of salary overshadows educational activities. The teaching profession is the profession that produces other professions. If you fail to address the needs and realties of teachers, you will also lose the other profession. Now nobody wants to be a teacher and those in the teaching profession also want to leave. The teaching profession failed to attract better candidates to the profession. Students join the teaching profession if and only if they could not find a place in other fields of study. The main reason is the salary. Everybody knows that teaching profession is a doorway to poverty. If you become a teacher you cannot enjoy the benefits and privileges other professionals enjoy. This is onslaught against the teachers and teaching profession. This is a devastating effect on the whole process of teaching and learning.... If you are always thinking to leave the profession, you do not have an interest and motivation to develop and update your knowledge and skills... 


\section{Macrothink}

It can be learned from the participants' description that low salary of teachers' is endangering the teaching profession. It affects their commitment, satisfaction and enforces them to look for other job. Participants state that failure to attract better candidates to the system and inability to retain those in the system jeopardizes the human development effort of the country. During the interviews and focus group discussions, participants emphasized that unless teachers are provided with an income that professional educators deserve it is difficult for the teaching profession to attract the best and brightest candidates which in turn in their own word "has a damaging effect in the whole process of education". They went on explaining the issue of pay and ask the question "How can teaching profession attract the best candidates to education if they aren't paid the same as people in other fields with the same qualification and experience?" Our research findings also affirmed what Mulkeen et al. (2007) found in their study conducted in African countries. They portrayed that when teachers' standard of living is so low that their basic needs are not met, teachers do not give priority to their teaching responsibilities, which also includes active engagement in professional development.

\section{Discussion}

Schools play an important role in preparing students for the changing and challenging world and teachers are crucial in ensuring the quality of education those students receive. However, this is only possible when teachers are motivated enough to update their knowledge and skills on continuous bases and perform their roles effectively and adequately. Especially in countries like Ethiopia, where teachers are the major source of knowledge, skills and dispositions for students, what teachers practice in the classroom matters. This research examined teachers' motivation for teaching and professional development. Our findings showed that two most important factors influencing teachers' motivation were the salary and the missing link between performance and reward. In addition, several other factors related to these two were identified. The hypothetical relationship between those motivational factors are presented in figure 1.



Figure 1. Hypothetical relationships between the motivational factors 


\section{Mll Macrothink}

The findings showed that the issues of salary and missing link between performance and reward were the biggest motivational challenge for teaching and participation in professional development in Ethiopia. The finding affirmed previous studies (see, Bennell, 2004; Adelabu, 2005; Mulkeen et al., 2007; Rasheed, Aslam \&Sarwar, 2010; Chireshe \& Shumba, 2011) conducted in developing countries that state low salary as a reason behind demotivation of teachers. The authors have stated that teachers are highly dissatisfied with their remuneration which resulted in low morale and thus poor performance among teachers. In our findings, we also observed that teachers are paid low salary that fall a short to address their quest for basic needs (foods, cloth and shelter). This low salary coupled with inflation make the cost of living unbearable for the teachers. Consequently, teachers' motivation to stay in the profession and sustain their involvement in education practices lowered. This situation affects teachers' love for the profession and their desire to make a difference in students learning. According to the findings of this study, the low pay for teachers force them to look for better paying jobs, which in turn undermine their participation in professional learning opportunities within the teaching profession.

If the need for physiological needs (need for food, water, sleep, physical comfort etc) are not satisfied, teachers may not be able to reach the next level of needs identified by Maslow (1954) self-fulfillment. For Maslow, basic needs must be satisfied first in order to be concerned with higher order needs, such as the need for growth, accomplishment, self-actualization. Teachers' responses showed that they want reasonable pay that addresses their needs in order to develop passion for their profession and interest for professional growth. If this need is not satisfied, teachers may lack enthusiasm for profession, which may negatively affect their motivation to perform teaching assignment adequately and the desire to participate in professional development activities. Bennell (2004) states that only when the basic needs have been met it is possible for higher-order needs, which are the basis of true job satisfaction, to be realized. If the basic needs remain unmet they undermine and discourage the need for professional growth and development. This is caused by dissatisfying teachers and enforcing them to leave the profession (Voke, 2002). This is in line with Herzberg's concept of salary as a hygiene factor that may cause dissatisfaction with the work. According to his theory, the school leaders need to eliminate the dissatisfactions teachers are experiencing and, help them find satisfaction.

In our findings, we also observed that the absence of reasonable professional pay for teachers is a discouraging prospect that lowered the value of the teaching profession in the society. The participants perceived that the teaching occupation is not valued by society, and because of this their motivational level is affected. Another issue that demotivated teachers and drive away them from the teaching profession is the wage gap between teaching and non-teaching professionals. Teachers not only received salary below the living wage but also low compared to other professions. Therefore, teachers perceived that they are treated unfairly and plead for reasonable pay.

According to Equity theory, individuals want to be compensated fairly for their contributions (the outcomes they experience match their inputs). The essence of this theory is that when people feel fairly or advantageously treated they are more likely to be motivated; when they 
feel unfairly treated they are highly prone to feelings of disaffection and demotivation. Equity theorists also state that the extent of demotivation is proportional to the perceived disparity with other people or inequity, for some people just the smallest indication of negative disparity between their and other people's situation is enough to cause massive disappointment and a feeling of considerable injustice, resulting in demotivation. People respond to the situation in different ways, some people reduce their effort, some seek to improve the outputs by making claims or demands for more reward, some people quit the job and seek an alternative job. The findings revealed that teachers feel that teaching profession is the least paid and most disrespected profession in the country. The data also showed that teachers respond to the situation by reducing their effort and seeking an alternative payable job.

The other demotivating factor indicated in our findings is the absence of link between performance/effort and reward. Participants' experienced that there is no any incentive, reward or even recognition for the effort teachers made to update themselves and improve classroom experiences. This condition signaled a message that hard working and participation in professional development is not valued which in turn demoralize and demotivate teachers. As Shah et al. (2012) argue, reward and recognition along with many other factors can have an effect on the job satisfaction and motivation of teachers. Adams (1965) asserts that when teachers encounter inequity they will tend to respond negatively and start to lose interest in teaching, which is also confirmed in our study. For instance, if a teacher works longer hours than his/her colleague, yet receives the same salary or reward or promotion the teacher would perceive inequity in the form of under-reward.

Vroom suggested that individuals choose work behaviors that they believe lead to outcomes they value. In deciding how much effort to put into work, individuals are likely to consider expectancy, instrumentality and their valence. Theorists agree that the three factors of motivation in the expectancy theory collectively determine the overall level of motivation. In other words if a worker has a high degree of effort, this translates to increased performance which in turn leads to the reward. In our study teachers unanimously expressed their dissatisfaction about the missing link between their effort, performance and reward, which, as they described, negatively affects their motivation for teaching and participation in professional development. Regarding recognition, which Herzberg (1968) considers as an important motivator, teacher respondents stated that there is no recognition available to them.

Literature on motivation provides wide and diverse approaches explaining what would be the best ways for motivating people. They draw on several theoretical perspectives and employ differing views of the origins or sources of motivation. Some theories propose that internal states (referred to as drives, needs or motives) within individuals energize and direct their behavior. Others attempt to describe how behavior is directed and sustained, and focus on cognitive processes such as thoughts, beliefs and values that people use to make choices regarding their behavior at work. In our study, we attempted to explore teachers' motivation for teaching and professional development by employing various motivational theories representing the two views. These include Maslow's hierarchy of needs, Herzberg's two factor theory, Expectancy theory and Equity theory. Our study indicates that all of these 
theories can be used for understanding teachers' motivation. Different theories explain motivational mechanisms in different terms but the common conclusion was that teachers were poorly motivated to teaching and taking part in professional development due to a combination of low salary and missing link between performance and reward.

To ensure the highest return on professional development investments, it is important to make sure that teachers are willing, committed and motivated to develop themselves as well as their schools. They need to become a life-long learner by learning to keep up with changes through professional development opportunities and by teaching with passion. To this end, school leaders and administrators need to find out ways to increase teacher motivation. In our study, we found salary and absence of link between performance and reward as the biggest motivational challenge for teachers in the Ethiopian context. It is easy to see direct practical implications from these findings and recommendations for enhancing teachers work conditions. Moreover, we expect further valuable contributions to the discourse concerning teachers' motivation by conducting a large scale survey research in a similar context, and conducting comparative studies of developed and developing countries regarding the major motivational challenges for teachers.

\section{References}

Abdel Fattah, S.M. (2010). Longitudinal effects of pay increase on teachers' job satisfaction: A motivational perspective. The Journal of International Social Research, 3(10), 11-21.

Adams, J.S. (1965). Inequity in social exchange.In Berkowitz (Ed.), Advances in experimental social psychology. New York, Academic Press. http://dx.doi.org/10.1016/S0065-2601(08)60108-2

Adelabu, M. A. (2005). Teacher motivation and incentives in Nigeria.London, DFID.

Akiba, M., Chiu, Y., Shimizu, K., \& Liang, G. (2011). Teacher salary and national achievement: A cross-national analysis of 30 countries. International Journal of Educational Research, 53: 171-181. http://dx.doi.org/10.1016/j.ijer.2012.03.007

Al-Habsi, S. K. (2009). Motivating teachers in times of change.In M. Wyatt \& J. Atkins (Eds.), Research perspectives on education in Oman. Sultanate of Oman:Ministry of Education.

Barmby, P.(2006). Teacher recruitment andretention.Educational Research,48 (3):248-265.

Baron, H., Henley., S., McGibbon, A., \&McCarthy, T. (2002). Motivation questionnaire manual and user's guide. Sussex: Saville \&Holdsworth Limited.

Bennell, P. (2004). Teacher motivation and incentives in sub-Saharan Africa and Asia.Knowledge and Skills for Development, Brighton, UK.

Bennell, P. ,\&Akyeampong, K. (2007). Teacher Motivation in Sub-Saharan Africa and South Asia.DFID Educational Paper No. 71. London, DFID. 
Chireshe, R.,\&Shumba, A. (2011). Teaching as a Profession in Zimbabwe: Are Teachers Facing a Motivation Crisis? Journal of social science, 28(2): 113-118.

Darling-Hammond, L., Wei, R., Andree, A., Richardson, N., \& Orphanos, S. (2009). Professional learning in the learning profession: A status report on teacher development in the US and Abroad. Dallas: National Staff Development Council.

Dehaloo, G. (2011). The motivation and job satisfaction of secondary school teachers in kwazulu-natal: an education management perspective. Unpublished thesis, University Of South Africa.

Estes, B., \&Polnick,B. (2012).Examining Motivation Theory in Higher Education: An Expectancy Theory Analysis of Tenured Faculty Productivity. International Journal of Management, Business, and Administration, 15(1):1-7.

Evans, A. (2001). Staff recruitment and retention: A guide to effective practice. London:Spiro.

Fiore, D. J. (2009).Introduction to educational administration: Standards, theories, and practice: Eye On Education.

Fuhrmann, T. D.(2006). Motivating Employees.Advances in Diary Technology, 18, 93-101.

Geren, B. (2011). Motivation: Chinese theoretical perspectives.Journal of Behavioral Studies in Business, 3, 1-10. Retrieved from: http://www.aabri.com/manuscripts/10692.pdf

Guskey, T. (2000).Evaluating professional development.Thousand Oaks, CA: Corwin Press, Inc.

Harris, A., \& Jones, M. (2010).Professional learning communities and system improvement.Improving Schools, $\quad 13(2), \quad 172-181$. http://dx.doi.org/10.1177/1365480210376487

Heikkinen, H. L. T., Jokinen, H., \& Tynjälä, P. (2008). Reconceptualising mentor as a dialogue.In G. Fransson\& C. Gustafsson (Eds.), Newly Qualified Teachers in Northern Europe: Comparative Perspectives on Promoting Professional Development (pp. 107-124).Gävle University Press: Gävle.

Heikkinen, H.L.T., Jokinen, H.,\& Tynjälä, P. (2012). Teacher education and development as lifelong and lifewide learning. In H.L.T. Heikkinen, H. Jokinen \& P. Tynjälä (eds) Peer-group mentoring for teacher development. (pp. 3-30). London: Routledge.

Herzberg, F. (1968). One More Time: How Do You Motivate Employees? Harvard Business Review 46:53-62.

Herzberg, F., Mausner, B., \& Snyderman, B. B. (1959).The motivation to work. New York: John Wiley \& Sons. 
Huitt, W. (2001).Motivation to learn: An overview. Educational PsychologyInteractive.Valdosta, GA: Valdosta State University. Retrieved from http://www.edpsycinteractive.org/col/motivation/motivate.html.

Karabenick, S. A., Conley, A. (2011). Teacher Motivation for Professional Development.Math and Science Partnership.Motivation Assessment Program, University of Michigan, Ann Arbor, MI 48109.

Kroth, M.(2007).Maslow-Move Aside! A Heuristical Motivation Model for Leaders in Career and Technical Education.Journal Of Industrial Teacher Education,44(2): 5-36.

Majerič, M., Leskošek, B., \&Erpič, S.C. (2011).The motivation of physical education teachers to participate in permanent professional training courses: an analysis of selected factors.KinesiologiaSlovenica, 17(1), 28-41.

Maslow, A.H. (1954). Motivation and personality.New York, Harper \& Row.

McShane, S.L. \& Von Glinow, M. (2003).Organisationalbehaviour.Emerging realities for the workplace revolution. Sydney: McGraw-Hill.

Miner, J. B. (2005).Organizational behavior I. Essential theories of motivation and leadership.New York: M.E. Sharpe, Inc.

Mulkeen A, Chapman, D.W., DeJaeghere, J.G., Leu, E. (2007). Recruiting, Retaining and Retraining Secondary School Teachers and Principals in Sub-Saharan Africa. World Bank:Washington DC. http://dx.doi.org/10.1596/978-0-8213-7066-7

Ololube, P. O. (2005). Teachers Job Satisfaction and Motivation for school effectiveness: An assessment. Unpublished thesis, University of Helsinki, Finland.

Porter, L. W., \& Lawler, E. E. (1968).Managerial attitudes and performance. Homewood, IL: Irwin-Dorsey.

Ramlall, S. (2004).A Review of employee motivation theories and their implications for employee retention within organizations.The Journal of American Academy of Business,52-63.

Rasheed M. I., Aslam, H.D., \&Sarwar, S. (2010). Motivational Issues for Teachers in Higher Education: A Critical Case of IUB. Journal of Management Research, 2(2),1-23. http://dx.doi.org/10.5296/jmr.v2i2.349

Schultz, D. P., \& Schultz, S. E. (2009). Theories of Personality. United States of America: Wadsworth, Cengage Learning.

Shah, J. M., Ur-Rehman, M., Akhtar, G., Zafar, H., \& Riaz, A. (2012).Job satisfaction and motivation of teachers of public educational institutions. International Journal of Business and Social Science, 3(8), 271-281.

Spector, P. (2008). Industrial and Organisational Behaviour ( $5^{\text {th }}$ ed.). New Jersey:John Wiley \& Sons. 


\section{Macrothink}

Journal of Studies in Education

ISSN 2162-6952 2015, Vol. 5, No. 2

Voke, H. (2002). Understanding and responding to the teacher shortage.ASCD InfroBrief, 29, $1-17$.

Vroom, V.H., \& Deci, E.L. (1992).Introduction to the second edition.In V.H. Vroom and E.L. Deci (Eds.), Management and Motivation. London: Penguin Group.

Wright, M. D. (1985). Relationships among esteem, autonomy, job satisfaction and the intention to quit teaching of downstate Illinois industrial education teachers. Unpublished doctoral thesis, University of Illinois.

Yung-Hsiang, H. (2000). Motivation in organisations: The need for a critical systemic approach. Unpublished doctoral thesis, University of Hull.

Zhilla, E. (2013). Work Motivation in the Academe: The Case of Albanian Public Universities. Journal of Educational and Social Research, 3(1), 93-98. 